\title{
Nitric Oxide Detection Using Electrochemical Third-generation Biosensors-Based on Heme Proteins and Porphyrins
}

Filipa O. Gomes, ${ }^{[a, b]}$ Luísa B. Maia, ${ }^{[b]}$ Cristina Cordas, ${ }^{[b]}$ Cristina Delerue-Matos, ${ }^{[a]}$ Isabel Moura, ${ }^{[b]}$ José J. G. Moura, ${ }^{[\mathrm{b}]}$ and Simone Morais*[a]

\begin{abstract}
Nitric oxide radical (NO) is a signalling molecule involved in virtually all forms of life. Its relevance has been leading to the development of different analytical methodologies to assess the temporal and spatial fluxes of NO under the complex biological milieu. Third-generation electrochemical biosensors are promising tools for in loco and in vivo NO quantification and, over the past years, heme proteins and porphyrins have been used in their design. Since there are some limitations with the biorecognition element directly adsorbed onto
\end{abstract}

the electrode surface, nanomaterials (carbon nanotubes, gold nanoparticles, etc.) and polymers (cellulose, chitosan, nafion $^{\circledR}$, polyacrylamide, among others) have been explored to achieve high kinetics and better biosensor performance. In this review, a broad overview of the field of electrochemical third-generation biosensors for $\mathrm{NO}$ electroanalysis is presented, discussing their main characteristics and aiming new outlooks and advances in this field.

Keywords: Third-generation biosensors $\cdot$ Nitric oxide detection $\cdot$ Heme proteins $\cdot$ Porphyrins $\cdot$ Kinetic and electroanalytical parameters.

[a] F. O. Gomes, C. Delerue-Matos, S. Morais

REQUIMTE-LAQV, Instituto Superior de Engenharia do Instituto Politécnico do Porto, Rua Dr. António Bernardino de Almeida, 431, 4249-015 Porto, Portugal

+351228340500

+351228321159

E-mail: sbm@isep.ipp.pt

[b] F. O. Gomes, L. B. Maia, C. Cordas, I. Moura, J. J. G. Moura REQUIMTE-LAQV, Departamento de Química, Faculdade de Ciências e Tecnologia, Universidade Nova de Lisboa, Campus de Caparica, 2829-516 Caparica, Portugal 


\section{Introduction}

Nitric oxide radical ( ${ }^{\circ} \mathrm{NO}$, herein abbreviated as $\left.\mathrm{NO}\right)$ is an ubiquitous molecule, involved in numerous biological processes in virtually all forms of life, from bacteria to humans. NO is known for long as key player of the biogeochemical cycle of nitrogen (Figure 1), participating in different prokaryotic pathways crucial to the planet "recycling" of nitrogen and, consequently, to life on Earth [1]. In fact, NO may have been the first deep electron sink on Earth, before the emergence of dioxygen [2,3]. Even today, the formation of the $\mathrm{N}-\mathrm{N}$ bond, essential to ultimately produce dinitrogen and, thus, accomplish the complete biological "recycling" of nitrogen, is only possible with the oxidizing power of $\mathrm{NO}$ (as far as is known) [1].

NO participates in two "classic" prokaryotic "respiratory" pathways, where nitrogen compounds are used as electron acceptors to derive energy: denitrification and anaerobic ammonium oxidation (AnAmmOx). In denitrification [4] (Figure 1, blue arrows), nitrate is anaerobically reduced to dinitrogen, through four sequential reactions, catalysed by specific metalloenzymes. In this pathway, NO is formed from nitrite, in a reaction catalysed by nitrite reductases, and is converted into nitrous oxide by a nitric oxide reductase. In AnAmmOx [5] (Figure 1, grey arrows), ammonium is anaerobically oxidised to dinitrogen in a two steps pathway, where ammonium is first oxidised by NO to yield hydrazine, in a reaction catalysed by the hydrazine synthase; the necessary NO is formed via nitrite reduction by nitrite reductases. In addition to these well-known "classic" pathways, several new processes are being identified, revealing the great biological versatility of NO [1]. Particularly interesting is the novel "denitrification/intra-aerobic methane oxidation" pathway that links the nitrogen and carbon cycles (Figure 1, violet arrows) [6]. In this puzzling pathway, strictly anaerobic organisms use NO to produce their own (endogenous) dioxygen supply to oxidise methane and other alkanes, while simultaneously produce dinitrogen.

More recently, it became clear that NO is not just a "prokaryotic molecule" or an environmental issue (associated with the depletion of the ozone layer). In 1987, NO was identified as the elusive endothelium-derived relaxing factor that regulates blood vessel vasodilation in mammals cardiovascular system [7-10], a discovery that was latter (1998) distinguished with the Nobel Prize in Physiology or Medicine, awarded to Furchgott, Ignarro and Murad. Presently, it is clear that the signaling functions of NO are not restricted to mammals, but are ubiquitous in virtually all forms of life, from bacteria to humans.

In humans, NO controls a plethora of functions, not only the well-known vasodilation (through the activation of guanylate cyclase), but also neurotransmission, immune response, platelet aggregation, apoptosis and gene expression, and mediates a wide range of both anti-tumor and anti-microbial activities [11]. Consequently, NO is involved in several pathological conditions, either when it is not produced in sufficient concentrations, as is the case of hypertension [12,13], impotence $[14,15]$, arteriosclerosis $[16,17]$ or susceptibility to infection [18], or when it is 


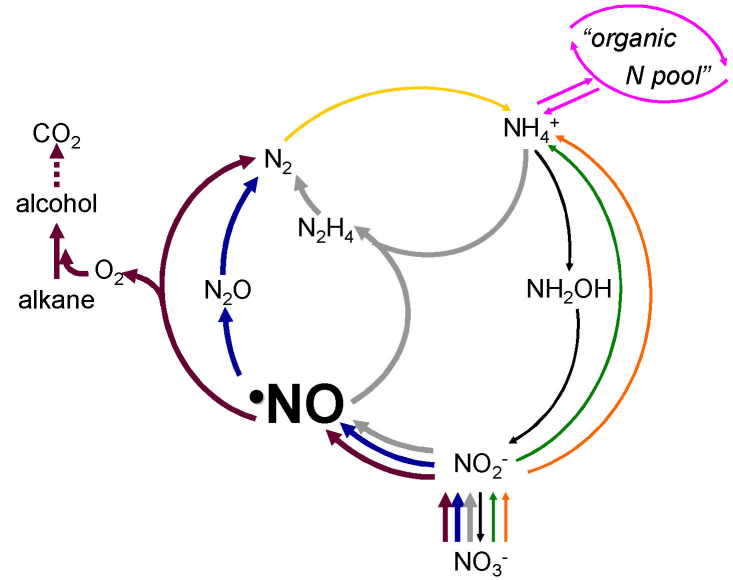

Fig. 1. Overview of the biochemical cycle of nitrogen. Denitrification, blue arrows; AnAmmOx, grey arrows; "denitrification/intraaerobic methane oxidation", violet arrows; dinitrogen fixation, yellow arrow; assimilatory ammonification, orange arrows; "organic nitrogen pool", pink arrows; dissimilatory nitrate reduction to ammonium, green arrows; nitrification and ComAmmOx, black arrows. The pathways where NO participates are highlighted with thicker lines (denitrification, AnAmmOx and "denitrification/intra-aerobic methane oxidation"). Adapted from reference [1] with permission.

produced in excess, as during chronic inflammation [20,21], septic shock syndrome [22], diabetes [23], multiple sclerosis [24] or Parkinson's and Alzheimer's diseases [25]. In humans, three tissue-specific isoforms of NO synthases (NOS), neuronal, endothelial and inducible NOS, catalyze the formation of NO from L-Arginine and dioxygen [26-28]. In addition, under hypoxic or anoxic conditions, when the dioxygen-dependent NOS activity is hampered, also nitrite is an important source of signalling NO [29-33]. The nitrite-dependent formation of NO is catalyzed by "non-dedicated" nitrite reductases, such as hemoglobin, myoglobin, xanthine oxidase and other metalloproteins present in the cells to carry out other functions.

This array of biological functions makes the metabolism of NO extremely important for the scientific community that pursuits new and old pathways of the nitrogen biogeochemical cycle, some of them linked with worrying environmental issues, as well as, new and old pathways of signaling $\mathrm{NO}$ and the associated physiological and pathological roles of NO. Yet, the advancement of our knowledge of the NO biology depends on methods capable of unequivocally identify it and precisely quantify it.

Measuring NO under biological conditions is not an easy task. The NO fast diffusion $\left(k \approx 10^{10}-10^{11} \mathrm{~mol}^{-1} \mathrm{Ls}^{-1}\right)$ and high reactivity with dioxygen $\left(k \approx 10^{6}-10^{7} \mathrm{~mol}^{-1} \mathrm{Ls}^{-1}\right)$, superoxide anion $\left(k \approx 10^{9}-10^{10} \mathrm{~mol}^{-1} \mathrm{Ls}^{-1}\right)$ and other radicals, as well as, with metalloproteins (mostly hemes and labile $[4 \mathrm{Fe}-4 \mathrm{~S}]$ centres) cysteine residues and other thiols, determine that NO has a very short half-life (typically within the seconds range), which greatly hinders the precise and accurate NO quantification [11,27,34]. To further complicate the subject, the range of NO concentrations is very wide; for example, in humans, the NO physiological concentration can range from $10^{-10}$ to $10^{-7} \mathrm{M}$ and reach micromolar levels under pathological conditions and immune responses [11,27,34]. Moreover, the NO studies often require its detection in very complex systems, containing other potentially interfering species present in much higher concentrations than NO itself, such as nitrite, nitrate, dopamine or ascorbate. NO research has been increasing in the last years and this boost demands the development of analytical techniques capable of precisely and accurately quantify NO levels and rates of production. Moreover, several methodologies have been developed to measure NO: (i) indirect detection, quantifying cyclic guanosine monophosphate (cGMP), a biologically active second messenger [35,36], or by the NO oxidation products, using fluorescent probes [37-42] or the Griess reaction [43-48]; (ii) direct detection, exploring different properties of NO, such as its radical nature, using electron paramagnetic resonance spectroscopy [41,49-51], its reactivity towards some metalloproteins (e.g., reaction with reduced hemoglobin and methemoglobin formation) or its ability to react with ozone to produce light, using chemiluminescence detection [52-54]. While most of these approaches display high sensitivity and selectivity for NO, all present specific limitations, with one main issue being the spatial resolution in vivo, which cannot be obtained with a "bulk" method.

\section{Electrochemical Detection of NO}

Electrochemistry has high potential to measure NO in biological fluids because it can detect $\mathrm{NO}$ in real time and in situ [55]. In addition, NO biosensors can be in the perfect size (small enough) to be used in many in vivo applications. According to the International Union of Pure and Applied Chemistry (IUPAC), sensors contain two basic functional units: a receptor and a transducer part. Sensors are normally designed to operate under well-defined conditions for specified analytes in specific samples [56]. Biosensors may be differentiated from sensors due to the biorecognition elements used in the receptor, which may be enzymes, antibodies, tissues, cells, organelles, membranes, among others $[57,58]$. Depending on the type of signal transduced, the classification of biosensors can be electrochemical, optical, piezoelectric, thermal/calorimetric [59]. Electrochemical biosensors offer several advantages, such as excellent detection limits, high specificity, easy miniaturization, portability, and ability to be used in turbid biofluids and in extremely low analyte volumes $[60,61]$. However, there may be some drawbacks to perform reliable electrochemical measurements in complex biological systems, such as lack of robustness, biofouling with surface electrode blockage, lack of stability, and/or deactivation of enzymatic activity $[62,63]$. Still, the evolution of first- to third-generation 
electrochemical biosensors has helped to simplify and enhance the transduction pathway [64]. In third-generation biosensors, the electrons involved in the redox processes are transferred directly between the enzyme or redox protein and the electrode surface to generate the response signal; no redox mediators are used oppositely to the second-generation electrochemical biosensors [65]. Moreover, the use of third-generation biosensors can allow to understand the mechanisms regarding several electron transfer processes [66]. Electrochemical reduction (on bare or modified electrodes) may be employed for NO detection studies but it is often difficult due to interference from oxygen, whose reduction happens faster than that of NO. As a result, the majority of electrochemical NO biosensors are based on the oxidation of NO to nitrite instead of NO reduction [67-69], with the exception of those based on heme proteins and porphyrins.

Biosensors of third-generation for NO detection were architected with hemoglobin ( $\mathrm{Hb})$, myoglobin $(\mathrm{Mb})$ and cytochrome $c$ (cyt $c$ ) proteins, peroxidase, as well as with porphyrins. This study is dedicated to review, discuss and compare the main characteristics of these biosensors, aiming new outlooks and advances in this field. The scientific literature available on NO reduction using electrochemical biosensors was reviewed from 1997 till 2017 and the following keywords were crossed in Thomson Reuters - Web of Science: direct electron transfer; third-generation biosensors; hemoglobin; myoglobin; cytochrome $c$; peroxidase; porphyrins; nitric oxide detection.

\section{Direct Electron Transfer Behavior of Heme Proteins and Porphyrins in Third-generation Biosensors}

The main advantages of these direct electron transfer (DET) systems are their simpler design and the potential to provide interference free detection [70]. However, one of the main problem in DET biosensors development may be the inaccessibility of the redox center of most redox enzymes and proteins, covered by several peptides, which may hamper the electron flow between the enzyme or protein and the electrode [71]. To promote DET, nanomaterials and polymers have been extensively used for electrode surface modification (Table 1). $\mathrm{Hb}, \mathrm{Mb}$ and cyt $c$ proteins, peroxidase, and porphyrins have been all immobilized onto suitable physical transducers. The available immobilization techniques are adsorption on thin films (physical; electrostatic - layer-by-layer, electrochemical doping, pre-immobilization on ion-exchange beads; retention in a lipidic microenvironment), entrapment (electropolymerization; amphiphilic network; photopolimerization; sol-gel process; polysaccharide-based gel; carbon paste; clay-modified electrodes), cross-linking with natural or synthetic molecules (glutaraldehyde or carbodiimide), direct attachment by ionic or covalent bonding (activation of carboxylic or amino groups) and affinity (biotin(strept)avidin; metal-ion chelator; lectin-carbohydrate) [72]. The selected strategy has a major impact on biosensor performance (sensitivity, reproducibility and response time) and stability. The biorecognition element structure and activity should remain unchanged after immobilization (to maximize sensitivity), and it should intimately and strongly link to the transducer surface (to maximize stability). In addition, the substrate diffusion should take place easily. The employed approaches for preparation of third-generation biosensors for NO detection (Table 1) are mainly based on adsorption (physical $[73,74]$ and layer-by-layer [75-81]), entrapment [82-98] or covalent bonding [99-102]. Each method possesses its particular benefits and disadvantages. Adsorption have been mostly used due to its simplicity and because loss of activity is not significant [73-81]. However, leaching of the biocomponent has been reported as a problem due to the weak Van der Waal's forces and electrostatic or hydrophobic interactions established [103,104]. Entrapment maintains the bioactivity and has been contributing to reduce heme proteins and porphyrins leakage [82-98], but diffusional limitations may happen while high bioelement concentrations are required for electropolymerization [82-98]. Regarding covalent attachment, its predominant advantages are the reached high stability (leaching of the bioelement is not significant) and the absence of mass transfer limitations, although activity loss may be significant due to conformational changes of even denaturation of the enzyme or protein [72]. Also, toxic reagents (such as glutaraldehyde) have been commonly used for covalent coupling.

The choice of the working electrode is also crucial and several aspects, such as appropriate potential window, easy surface renewal, fast redox processes, reproducibility, easy miniaturization, low cost, the immobilized molecule and the substrate, should be considered. The privileged working electrodes have been glassy carbon (41\%) (GCE) and graphite pyrolytic (PGE) (31\%) electrodes, although gold electrodes (AuE) (9\%), powder microelectrode (PME) [86], carbon paste electrodes (CPE) [74], $\mathrm{SnO}_{2}$ and $\mathrm{TiO}_{2}$ electrodes [73], platinum (Pt) microelectrode [100] and carbon fiber microelectrodes (CFM) $[78,101]$ have been also explored but in a much lesser extend (Table 1).

\subsection{Hemoglobin}

$\mathrm{H} b$ is a hemic protein (containing four electroactive iron hemes - heme b groups) with a high molecular weight $(64500 \mathrm{~g} / \mathrm{mol})$ being a molecular vehicle of carbon dioxide and oxygen in red blood cells and also regulating the blood $\mathrm{pH}$ [105]. $\mathrm{Hb}$ is a molecule standard in bioelectrochemical studies due to its well-documented structure, known redox behavior in the vascular system of animals and because it is commercially available at moderated cost. Moreover, its heme $b$ center catalyzes the NO reduction in biological systems. Therefore, there has been 


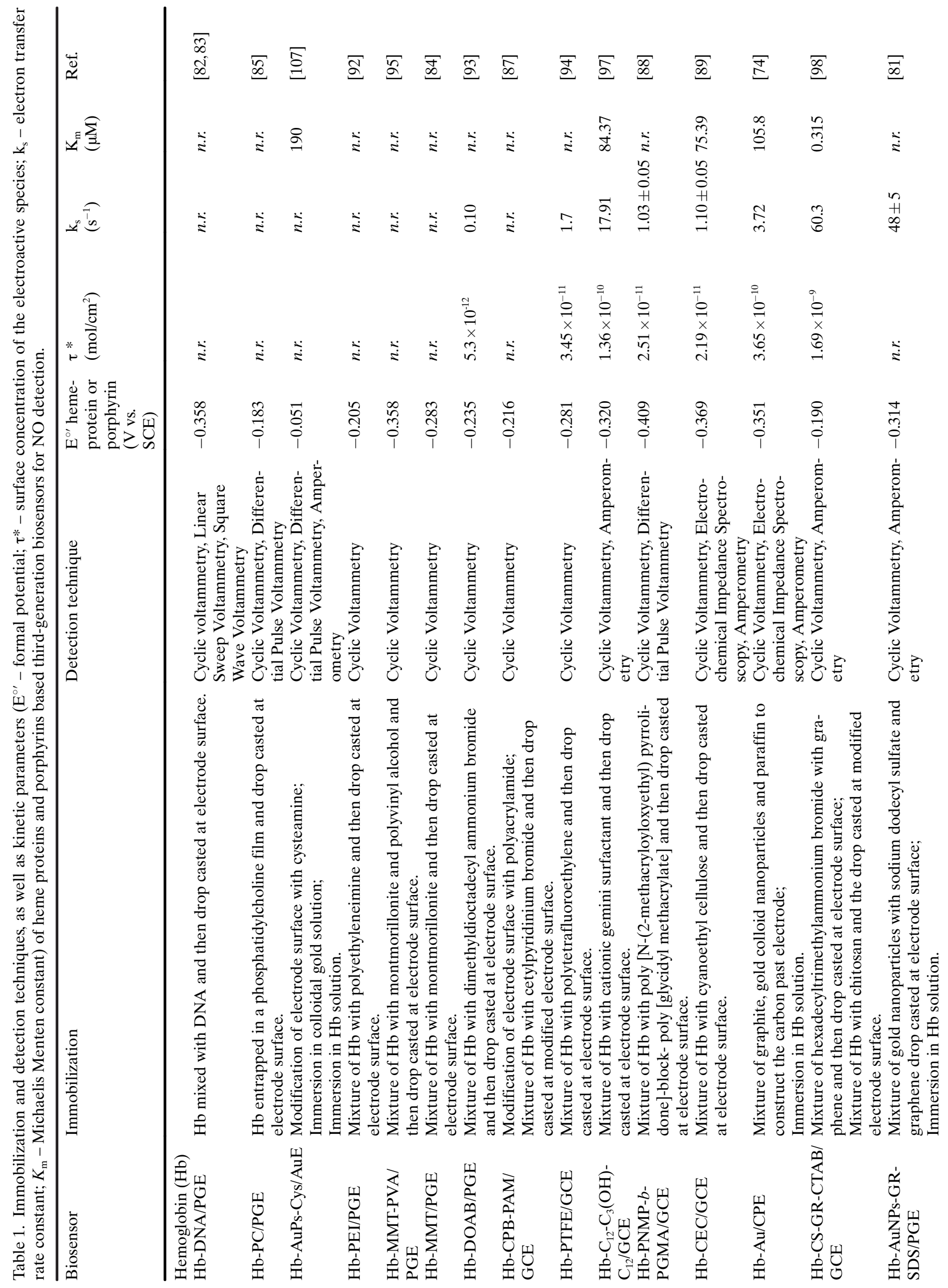




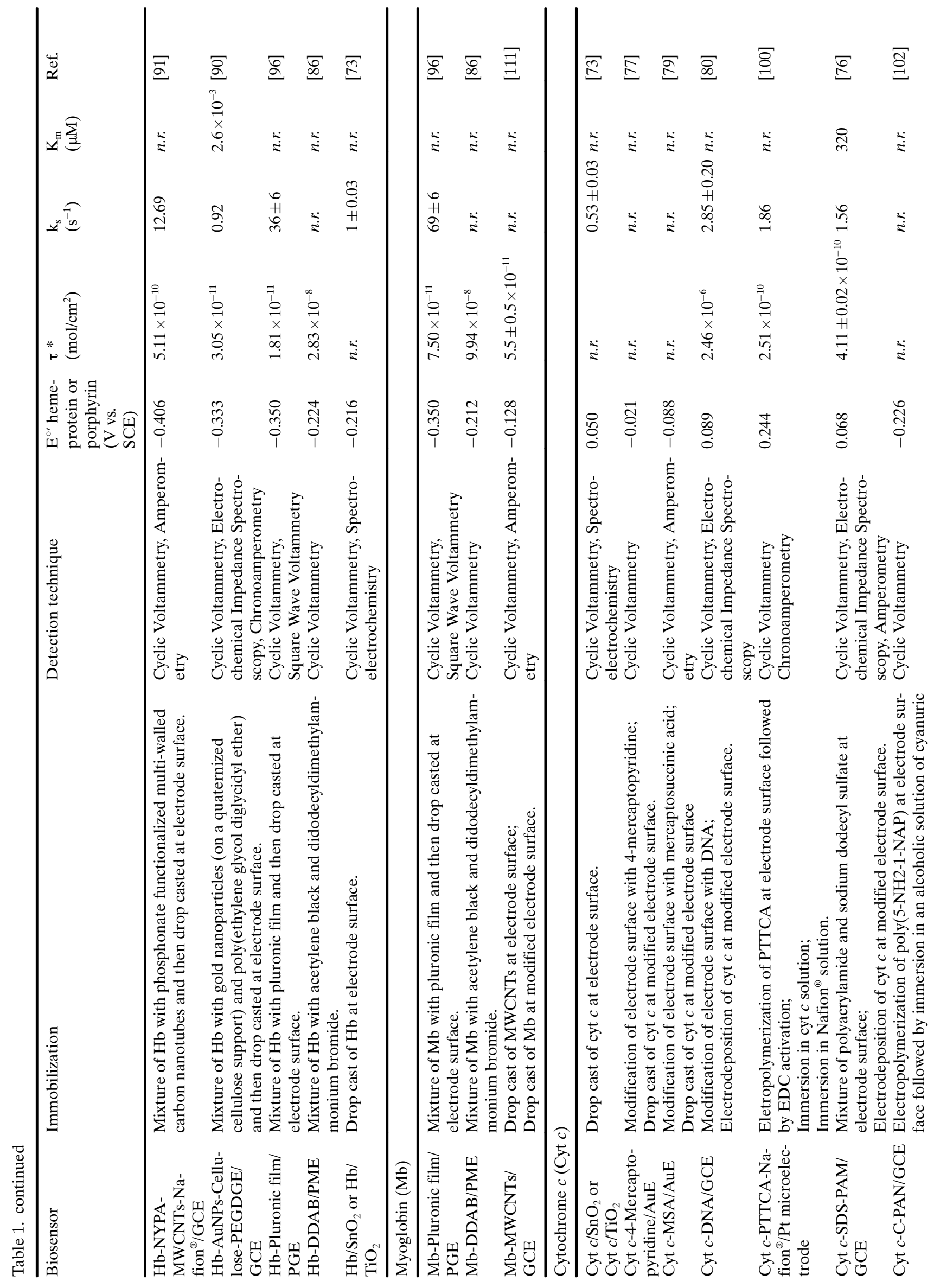




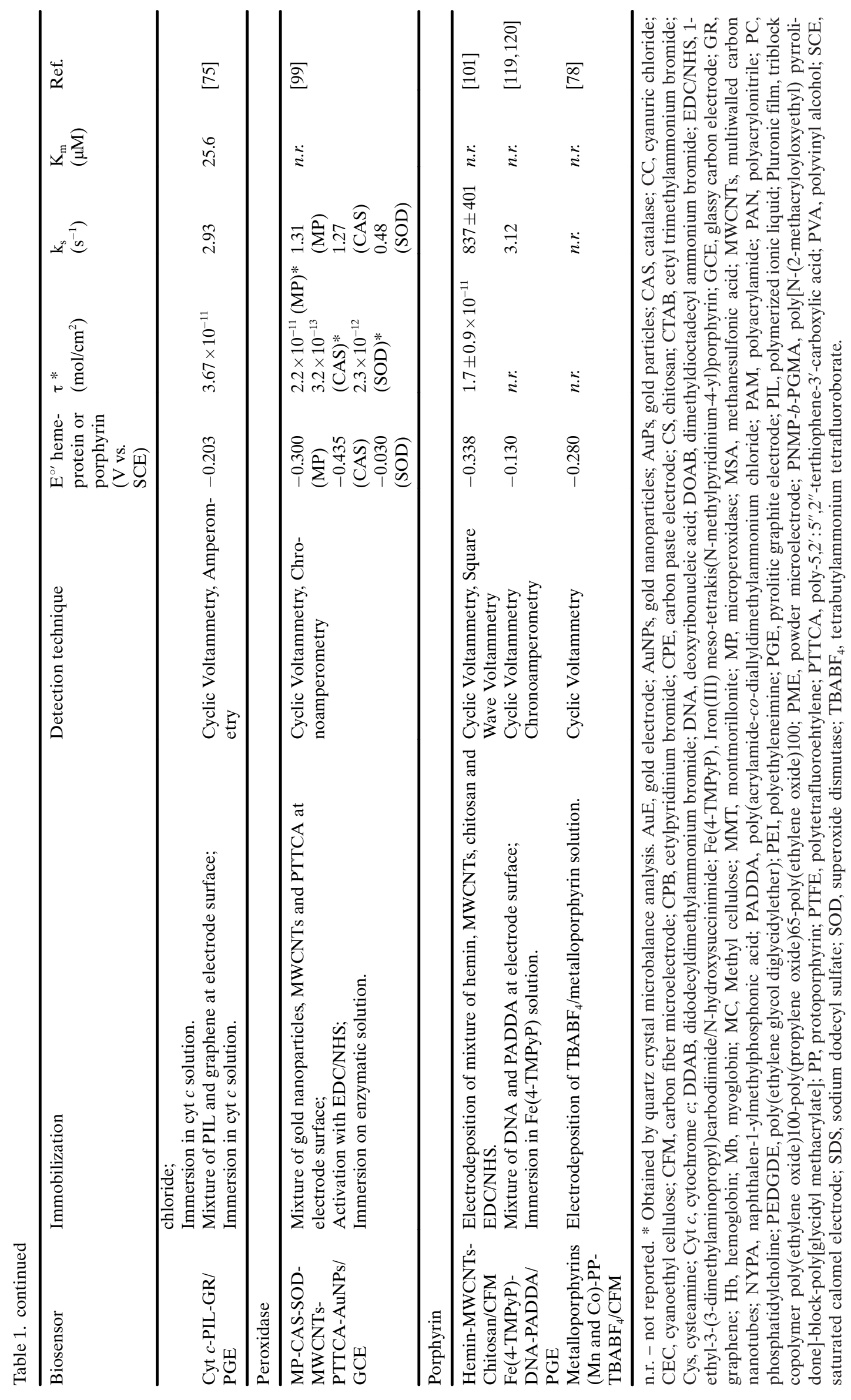


a huge interest to use $\mathrm{Hb}$ in $\mathrm{NO}$ biosensors development (around $59 \%$ of the total number of studies; Table 1).

The working electrode material and the type of surface modification used in each biosensor contributed to changes in the $\mathrm{Hb}$ formal potential $\left(\mathrm{E}^{\circ}\right.$ - formal potential, attained as the midpoint of reduction and oxidation potentials). According to the Table 1 , a large $\mathrm{E}^{\circ \prime}$ window has been reported for modified GCE, ranging from -0.409 [88] and -0.190 [98] V vs. SCE. A pair of welldefined redox peaks at $-0.384 \mathrm{~V}$ (anodic peak) and $-0.434 \mathrm{~V}$ (cathodic peak), corresponding to the lowest reported $\mathrm{E}^{\circ}$, were observed for a GCE modified by drop cast of a mixture of $\mathrm{Hb}$ with two polymers, the poly(onitro-benzyl-methacrylate-co-methyl-methacrylate-copoly(ethylene-glycol)methacrylate) (PNMP) and the poly(glycidyl methacrylate) (PGMA) [88]. Based on the attained results, the direct electrochemistry of $\mathrm{Hb}$ when entrapped in the prepared polymeric matrix film was considered a quasi-reversible process with $\mathrm{Hb}$ exchanging electrons directly (electron transfer rate constant $\left(\mathrm{k}_{\mathrm{s}}\right)=$ $\left.1.03 \pm 0.05 \mathrm{~s}^{-1}\right)$ with the electrode. Authors concluded that the used of an amphiphilic linear block copolymer can form an ordered biomembrane-like film, which provided an environment similar to that of redox proteins in native systems [88]. A highly sensitive NO biosensor based on GCE modification with a Hb-chitosan (CS)-graphene (GR)-hexadecyltrimethylammonium bromide (CTAB) nanomatrix with the highest formal potential of $-0.190 \mathrm{~V}$ vs. SCE was presented by Wen et al. [98]. CS, a natural biopolymer, showed good biocompatibility, nontoxicity, excellent film forming ability and high mechanical strength to immobilize proteins and also to act as dispersant for nanomaterials $[98,106]$. The interesting inherent properties of the CTAB surfactant were used to obtain a good dispersion of GR without particles aggregation. The composite film was deposited in a GCE and a combination of electrostatically and adsorptive interactions occurred, which improved the stability, selectivity and detectability making the developed approach suitable to use in amperometric devices. The reached very favorable electron transfer constant $\left(\mathrm{k}_{\mathrm{s}}=60.3 \mathrm{~s}^{-1}\right)$ was attributed to the fast electricity conduction and high effective surface area of GR offering electron-conducting tunnels that helped in electron transfer of the electroactive species [98]. In contrast to the considerable utilization of GCE, only one study reported the usage of $\mathrm{Au}$ electrodes due to their limited application for reduction processes detection [107]. Gu et al. [107] reported an $\mathrm{E}^{\circ}$ of $-0.051 \mathrm{~V}$ vs. SCE for an Au working electrode modified with gold particles (AuPs) and cysteamine (Cys) in a Hb-AuPs-Cys system. A pair of quasi-reversible redox peaks was also observed, with a significantly different cathodic $\left(\mathrm{E}_{\mathrm{pc}}=-0.130 \mathrm{~V}\right.$ vs. SCE $)$ and anodic $\left(\mathrm{E}_{\mathrm{pa}}=\right.$ $0.029 \mathrm{~V}$ vs. SCE) peak potentials due to the different transducer used, when compared with those reported for modified GCE [107]. In addition, for modified PGE, a similar $\mathrm{E}^{\circ \prime}$ range ( -0.358 to $-0.183 \mathrm{~V}$ vs. $\left.\mathrm{SCE}\right)$ as the one indicated for modified GCE may be observed corroborat- ing the analogous characteristics of these two types of electrodes. PME and CPE were used only in one study. $\mathrm{Xu}$ et al. [74] developed a novel biosensor based on $\mathrm{Hb}$ adsorbed on gold colloids modified carbon paste electrode ( $\mathrm{Hb} / \mathrm{Au}-\mathrm{CPE})$ with a $\mathrm{E}^{\circ \prime}$ of $-0.224 \mathrm{~V}$ vs. SCE [74]. Guo et al. [86] reported $-0.351 \mathrm{~V}$ vs. SCE for a modified PME (Hb/didodecyldimethylammonium bromide (DDAB)/ PME i.e. a similar $\mathrm{E}^{\circ \prime}$ as some GCE and PGE based transducers $[74,82,83,89,95,96]$. PME can be a promising electrode because it can contribute to decrease interferences from capacitive currents and uncompensated $i R$ [108].

\subsection{Myoglobin}

$\mathrm{Mb}$ is a small water-soluble cytoplasmatic hemoprotein (consisting of a single polypeptide chain of 154 amino acids) with a similar structure of $\mathrm{Hb}$, which has been also used in third-generation biosensors for $\mathrm{NO}$ analysis (Table 1). Mb has an available sixth coordination position at the heme iron, which makes it attractive for the detection of small coordinating species such NO molecules [109]. However, its heme site is much more blocked when compared to other heme groups of other proteins, such as in cyt $c$, being the main disadvantage of this protein for electrochemical studies [110]. Thus, only three studies were found concerning the use of $\mathrm{Mb}$ for $\mathrm{NO}$ electroanalysis (Table 1); comparison between $\mathrm{Hb}$ and $\mathrm{Mb}$ electrochemical behavior was made in two of the reported works [86,96]. In the work of Zhang et al. [111], MWCNTs were used to enhance DET between Mb and the electrode conferring excellent electrical conductivity and chemical stability. The reported $\mathrm{E}^{\circ \prime}$ was the highest, $-0.128 \mathrm{~V}$ vs. SCE, while for the other reported transducers based on PGE [96] and PME [86], values ranged from -0.350 and $-0.212 \mathrm{~V}$ vs. SCE, respectively. The formal potential and the structural conformation of $\mathrm{Hb}$ and $\mathrm{Mb}$ are similar and it was efficiently proved that both can be used for DET and for the design of NO biosensors.

\subsection{Cytochrome $c$}

Cyt $c$ is a stable protein containing covalently bonded heme $c$ groups with short-lived and transient response on a metal surface [80]. This protein plays an important role as electron transport in respiratory mitochondria chain, where cyt $c$ reductase functions as electron donor that delivers the electrons to cyt $c$ oxidase - the electron acceptor. Cyt $c$ shows peroxidase activity and can also catalyze several redox reactions such as hydroxylation and aromatic oxidation [112]. The $\mathrm{E}^{\circ \prime}$ obtained in cyt $c$-based biosensors for $\mathrm{NO}$ detection were in the large range of -0.226 to $0.244 \mathrm{~V}$ vs. SCE. This huge window can be explained by microenvironment changes, namely due to the protein immobilization in different matrices and transducers. Cyt $c$ works in several regions of the mitochondria and the cell, and changes in its environment may affect its redox characteristics. It is recognized that if 
a protein is not at the right potential in an electron transport chain, the consecutive steps may be disturbed affecting the whole process and promoting several reactions that could be undesirable [113]. Takahashi and de Torresi [102] reported the lowest value for the cyt $c \mathrm{E}^{\circ}$, $-0.226 \mathrm{~V}$ vs. SCE, using GCE modified with poly $\left(5-\mathrm{NH}_{2}-\right.$ 1-NAP) (PAN) and cyt $c$ covalently immobilized by cyanuric chloride (CC). The bridge component, CC, reacted with $-\mathrm{OH}$ groups of $\mathrm{PAN}$ and with the amino groups of the protein, attaching both by covalent bonds, revealing that the mechanism was not completely reversible and that the process at the surface electrode was not diffusional controlled, as expected for this type of immobilization system. The peak separation was larger than the value obtained from the theoretical electron transfer $(\mathrm{Fe}(\mathrm{III}) / \mathrm{Fe}(\mathrm{II})$ couple), probably because of the distance from heme of cyt $c$ to the electrode surface [102]. On the other hand, a completely different $\mathrm{E}^{\circ \prime}$ of $0.068 \mathrm{~V}$ vs. SCE was attained by Chen et al. [76] for the cyt $c$ immobilized with polyacrylamide (PAM) and sodium dodecyl sulfate (SDS) forming a cyt $c$-SDS-PAM system used in the same working electrode (GCE). A quasireversible redox process was observed while no signals were detected at the other electrodes without the immobilized protein. Also, the attained Nyquist plots and Randles circuit that fitted the impedance data showed that PAM, SDS and cyt $c$ were efficiently deposited on the bare GCE surface forming different kinetic barriers (electron transfer resistance (Rct) of $240 \Omega, 600 \Omega$ and $1200 \Omega$ for GCE, SDS/PAM/GCE and cyt $c /$ SDS/PAM/ GCE, respectively) [76]. So, the selected combination of polymer-surfactant, i.e. PAM-SDS, used as GCE surface modifiers allowed to form stable films with ordered multibilayer structure in aqueous solutions, indicating that DET between the cyt $c$ heme protein and the SDS-PAM/ GCE was improved [76]. The highest value of all previously reported $\mathrm{E}^{\circ}$, i. e. $0.244 \mathrm{~V}$ vs. SCE, was detected for Pt microelectrodes modified with two different polymers (poly(terthiophene-3-carboxylic acid) (PTTCA) and nafion $^{\circledR}$ ) [100]. The potential improvement was achieved by the use of microelectrodes due to the possibility to improve the signal-to-noise ratio and the ability to perform electrochemical measurements in highly resistive solutions. Less common working electrodes, namely AuE and $\mathrm{SnO}_{2} / \mathrm{TiO}_{2}$, were used to immobilized cyt $c$ originating near zero $\mathrm{E}^{\circ \prime}$ of -0.088 to $-0.021 \mathrm{~V}[77,79]$ and $0.050 \mathrm{~V}$ [73] vs. SCE, respectively.

\subsection{Peroxidase}

Peroxidase enzymes are redox glycoproteins presenting a $\mathrm{Fe}(\mathrm{III})$ protoporphyrin IX prosthetic group as the active site in enzyme catalyzed reactions [114]. Horseradish peroxidase (HRP) is the most studied of all peroxidase enzymes in amperometric biosensors using mostly mediators bound to the GCE surface to enhance the rate of electron transfer [106,115]. Still, Abdelwahab et al. [99] tested another class of peroxidase enzymes, the micro- peroxidase (MP), in unmediated biosensors for $\mathrm{NO}$ detection and quantification. This simple and small enzyme was obtained by tryptic digestion of horse heart cyt $c$ [99]. Abdelwahab et al. [99] tried to reduce the interferences of $\mathrm{H}_{2} \mathrm{O}_{2}$ and $\mathrm{O}_{2}{ }^{-}$during electroanalysis by co-immobilizing a multi-enzymes system with catalase (CAS) and superoxide dismutase (SOD), besides MP; $-0.300 \mathrm{~V}$ vs. SCE was reported for $\mathrm{E}^{\circ \prime}$ of MP. Authors used carbon nanomaterials (MWCNTs), gold nanoparticles (AuNPs) and poly-5,2':5", $2^{\prime \prime}$-terthiophene-3'-carboxylic acid (PTTCA) forming a MWCNTs-PTTCA-AuNPs nanocomposite to modify the GCE surface to offer a huge surface area for immobilizing the selected enzymes (CAS, SOD and MP) through covalent bond formation [99].

\subsection{Hemin and other Porphyrins}

Porphyrins are heterocyclic organic compounds that contain extensive $\pi$-system and form stable complexes with several metal ions [116]. Porphyrins can mimic the enzymatic or prosthetic centers and can also be used for NO detection and quantification. However, the electrocatalytic reduction of NO by adsorbed inorganic complexes such as porphyrins has been less considered than with heme proteins, but it is an interesting alternative approach considering the good affinity of NO to transition metals [117].

Hemin groups (a specific class of porphyrin) are known to adsorb rapidly on PGE surfaces forming an ordered structure. They are relatively inexpensive and have good stability in solution [118]. Other chemical groups, such as metalloporphyrins have been also tested in NO biosensors; formal potentials in the range of -0.338 [101] to $-0.130[119,120] \mathrm{V}$ vs. SCE have been reported. A cathodic and an anodic peak were attributed to the $\mathrm{Fe}(\mathrm{III}) / \mathrm{Fe}(\mathrm{II})$ couple of hemin at $-0.370 \pm 0.012 \mathrm{~V}$ and $-0.305 \pm 0.019 \mathrm{~V}$ vs. SCE, respectively, corresponding to the lowest $\mathrm{E}^{\circ}$ of $-0.338 \mathrm{~V}$ vs. SCE at an heminMWCNTs-chitosan using carbon fiber microelectrodes (CFM) [101]. The iron(III) meso-tetrakis(N-methylpyridinium-4-yl)porphyrin (Fe(4-TMPyP) was used to prepare a novel Fe(4-TMPyP) biosensor with Fe(4-TMPyP) immobilized with DNA and poly(acrylamide-co-diallyldimethylammonium chloride (PADDA), forming a DNA-boundporphyrin complex more stable and biocompatible. The developed complex showed the highest transfer rate $\left(\mathrm{k}_{\mathrm{s}}=\right.$ $3.12 \mathrm{~s}^{-1}$ ) and consequently the highest $\mathrm{E}^{\circ \prime}$ of $-0.130 \mathrm{~V}$ vs. SCE $[119,120]$. The peak potentials of the $\mathrm{Fe}(\mathrm{III}) / \mathrm{Fe}(\mathrm{II})$ couple are in agreement with the other related studies (Table 1) supporting the DET of porphyrins [78,117].

\section{Nitric Oxide Catalytic Reduction on Heme Proteins and Porphyrins Based Third-generation Biosensors}

The evaluation of the reported biosensors characteristics has been made using different electrochemical techniques. 
Cyclic voltammetry (CV), square wave voltammetry (SWV), differential pulse voltammetry (DPV), amperometry and electrochemical impedance spectroscopy (EIS) are the most usual methods for NO reduction studies (Table 1).

\subsection{Proposed Mechanisms and Catalytic Potential of Nitric Oxide}

The different catalytic potentials $\left(\mathrm{E}_{\text {cat; }}\right.$ defined as the midpoint potential of the electrocatalytic wave [121]; Figure 2) obtained for NO reduction are presented in Table 2. A few works reported and discussed the possible mechanism of NO with heme-proteins, porphyrins and enzymes.

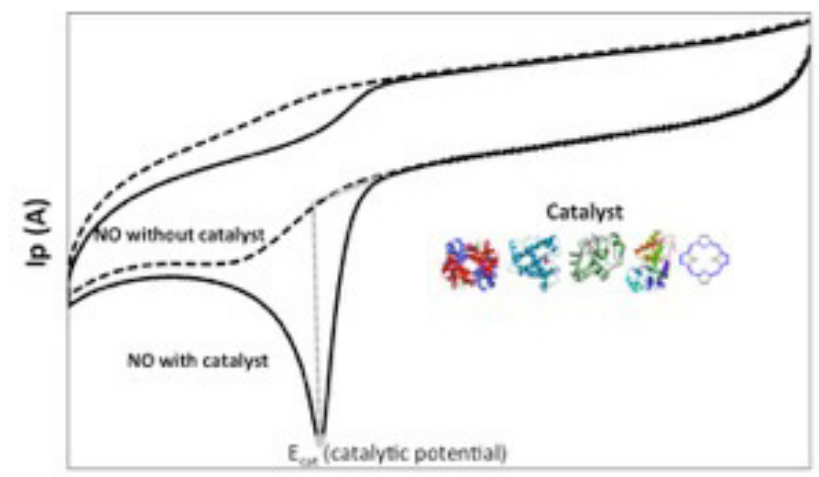

E (V)

Fig. 2. Illustration of the determination of the catalytic potential $\left(\mathrm{E}_{\mathrm{cat}}\right)$ of NO.

A NO $\mathrm{E}_{\text {cat }}$ between $-0.880 \mathrm{~V}$ [97] and $-0.580 \mathrm{~V}$ vs. SCE [85] was observed for $\mathrm{Hb}$ based-biosensors. Fan et al. [82] obtained a value of $\mathrm{E}_{\text {cat }}$ of $-0.684 \mathrm{~V}$ vs. SCE for HbDNA/PGE and proposed as possible mechanism (Eq. (1) and (2)):

$\mathrm{Hb}$ heme $\mathrm{Fe}(\mathrm{II})+\mathrm{NO} \rightarrow \mathrm{Hb}$ heme $\mathrm{Fe}(\mathrm{II})-\mathrm{NO}$

$\mathrm{Hb}$ heme $\mathrm{Fe}(\mathrm{II})-\mathrm{NO}+\mathrm{NO}+2 \mathrm{H}^{+}+2 \mathrm{e}^{-} \rightarrow$

$\mathrm{Hb}$ heme $\mathrm{Fe}(\mathrm{III})+\mathrm{N}_{2} \mathrm{O}+\mathrm{H}_{2} \mathrm{O}$

Although $\mathrm{He}$ and Zhu [87] suggested the same mechanism, a different $\mathrm{E}_{\text {cat }}$ of $-0.834 \mathrm{~V}$ vs. SCE was reported due to the different platform used for $\mathrm{Hb}$ immobilization (Hb-PAM-CPB/GCE). The use of waterabsorbent polymers and surfactants such as PAM and cetylpyridinium bromide (CPB), respectively, could have contributed to the diminution of NO peak potential. It should be also mentioned that the lowest value of $-0.880 \mathrm{~V}$ vs. SCE was also detected using a GCE modified with $\mathrm{Hb}$ entrapped in a cationic gemini surfactant film ( $\left.\mathrm{Hb}-\mathrm{C}_{12}-\mathrm{C}_{3}(\mathrm{OH})-\mathrm{C}_{12} / \mathrm{GCE}\right)$ [97]. The incorpora- tion of MWCNTs in the immobilization strategy did not affect the NO mechanism but helped to increase the electron transfer rate and consequently the reported NO potential are more positive [91].

An analogous catalytic mechanism for NO reduction (Eq. (3) to Eq. (7)) was suggested for $\mathrm{Mb}$ entrapped in pluronic films [triblock copolymer poly(ethylene oxide)100poly(propylene oxide)65-poly(ethylene oxide)100)] ( $\mathrm{E}_{\text {cat }}$ of $-0.800 \mathrm{~V}$ vs. SCE) [96]. Due to the interesting characteristics of pluronic films, such as the possibility to be used for controlled drug delivery, dispersion, and stabilization (among others), the selected polymers were used as a new type of materials that form films to successfully stabilize heme proteins at the PGE surface [96]. In the proposed mechanism, $\mathrm{HNO}_{2}$ is firstly formed (Eq. (3)), being subsequently disproportionated to $\mathrm{NO}$ and $\mathrm{NO}_{3}^{-}$(Eq. (4)). Then, the reaction showed in Eq. (5) was reported to occur at a formal potential of $-0.350 \mathrm{~V}$ vs. SCE while $-0.800 \mathrm{~V}$ vs. SCE was determined for the NO catalytic potential (Eq. (6)). In this reaction, heme $\mathrm{Fe}_{\mathrm{Fe}(\mathrm{II})}$ from $\mathrm{Mb}$ is combined with NO, forming the ferrous nitrosyl intermediate complex of heme $\mathrm{Fe}_{\mathrm{F}(\mathrm{II})} \mathrm{NO}$. This complex is then reduced at the transducer surface (Eq. (7)) and releases heme $\mathrm{Fe}_{\mathrm{Fe} \text { (II) }}$ again, forming a catalytic cycle. While the ultimate product of Eq. (7) is not yet clearly established, it is probably $\mathrm{N}_{2} \mathrm{O}$, as the literature suggested for other protein and enzymatic systems [96].

$$
\begin{aligned}
& \mathrm{NO}_{2}{ }^{-}+\mathrm{H}^{+} \rightarrow \mathrm{HNO}_{2} \\
& 3 \mathrm{HNO}_{2} \rightarrow 2 \mathrm{NO}+\mathrm{NO}_{3}{ }^{-}+\mathrm{H}^{+}+\mathrm{H}_{2} \mathrm{O} \\
& \text { heme }_{\mathrm{Fe}(\mathrm{III})}+\mathrm{H}^{+}+\mathrm{e}^{-} \rightarrow \text { heme }_{\mathrm{Fe}(\mathrm{II})} \\
& \text { heme }_{\mathrm{Fe}(\mathrm{II})}+\mathrm{NO} \rightarrow \text { heme }_{\mathrm{Fe}(\mathrm{II})}-\mathrm{NO} \\
& \text { heme }_{\mathrm{Fe}(\mathrm{II})}-\mathrm{NO}+\mathrm{H}^{+}+\mathrm{e}^{-} \rightarrow \text { heme }_{\mathrm{Fe}(\mathrm{II})}+\text { product }+\mathrm{H}_{2} \mathrm{O}
\end{aligned}
$$

De Groot et al. [117] described a different mechanism for porphyrins, namely the hemin-NO reaction, which led to the formation of $\mathrm{NH}_{2} \mathrm{OH}$ with an observed electrochemical followed by chemical reaction (EC) mechanism combined with proton transfer (Tafel slope of $62 \mathrm{mV} / \mathrm{dec}$ and $\mathrm{pH}$ dependence of $-42 \mathrm{mV} / \mathrm{pH}$ ). Some factors could have influenced these two different pathways including the mode of the electron transfer to the heme group, the residues surrounding the heme groups and the $\mathrm{pH}$ of the solution and more important the way in which a second NO bind to the active site [117]. In porphyrin basedbiosensors, a $\mathrm{E}_{\text {cat }}$ from -0.776 to $-0.566 \mathrm{~V}$ vs. SCE was reported for metalloporphyrins ( $\mathrm{Mn}$ and $\mathrm{Co})$-PP$\mathrm{TBABF}_{4} / \mathrm{CFM}$ [78] and Fe(4-TMPyP)-DNA-PADDA/ PGE $[119,120]$, respectively. Fe(4-TMPyP) influenced positively the electron transfer rate and the detected value was, in this way, more positive.

Cyt $c$ based biosensors using modification with polymerized poly (1-vinyl-3-ethyl imidazolium)bromide (PIL)- 


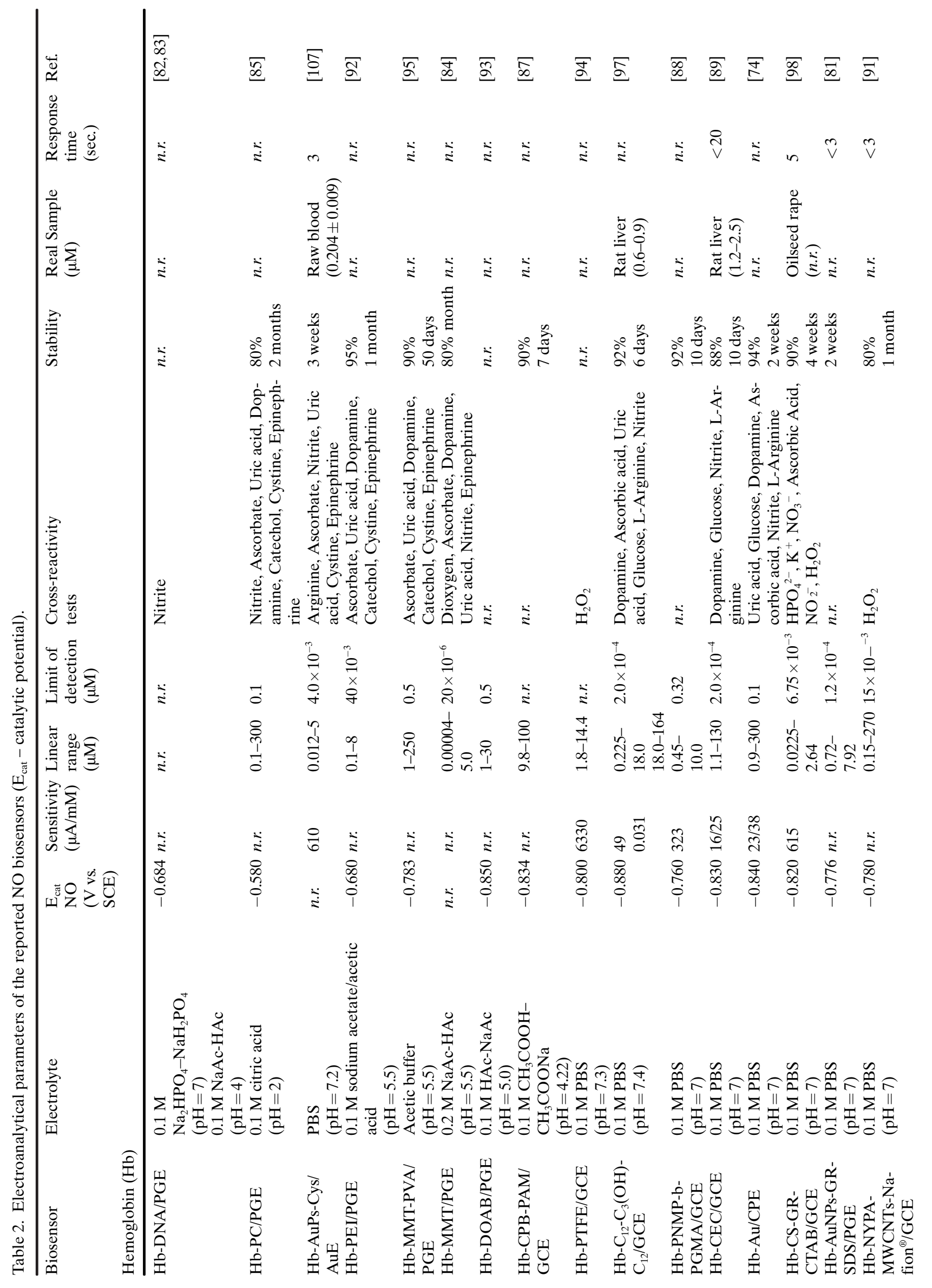




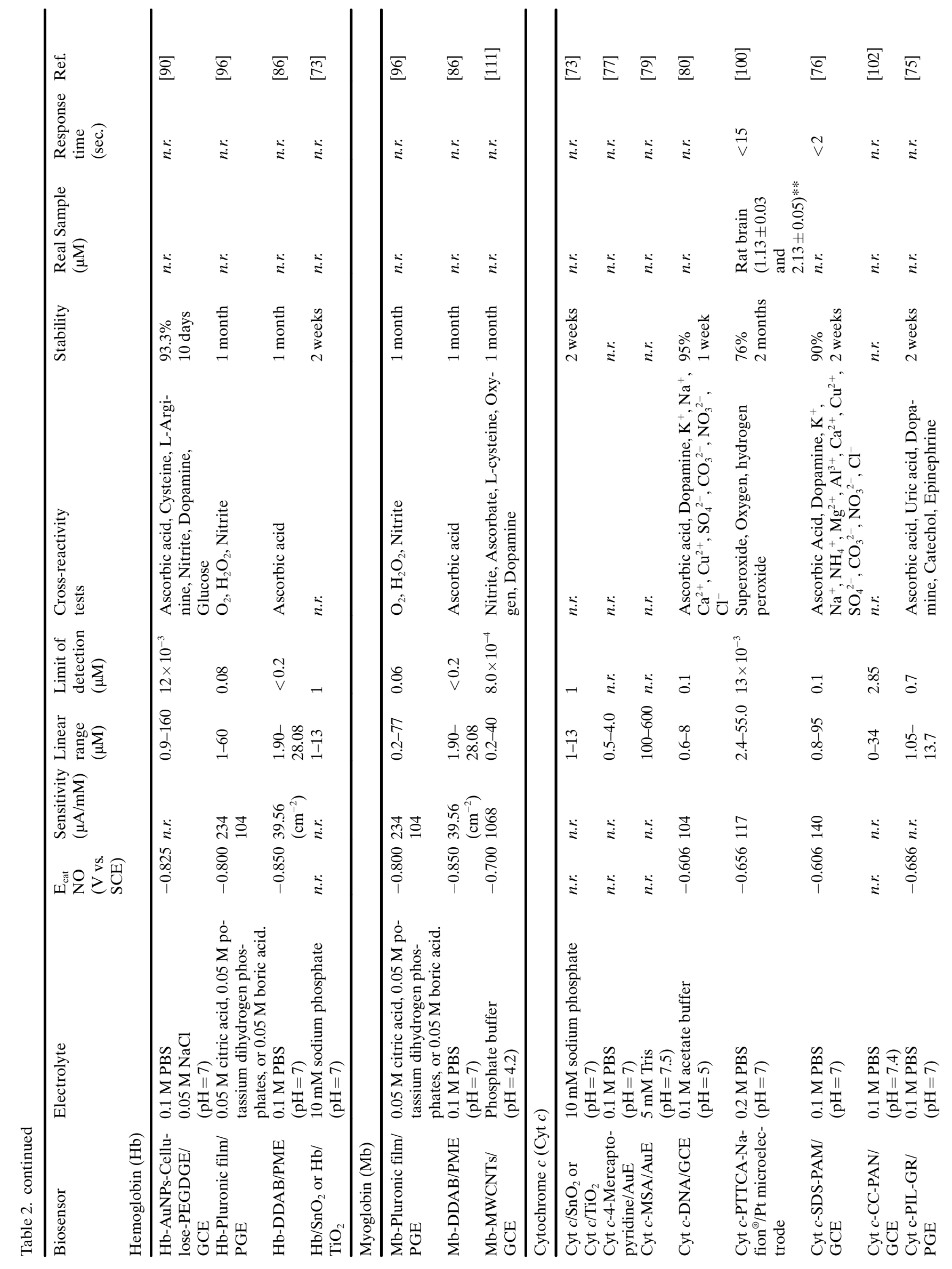




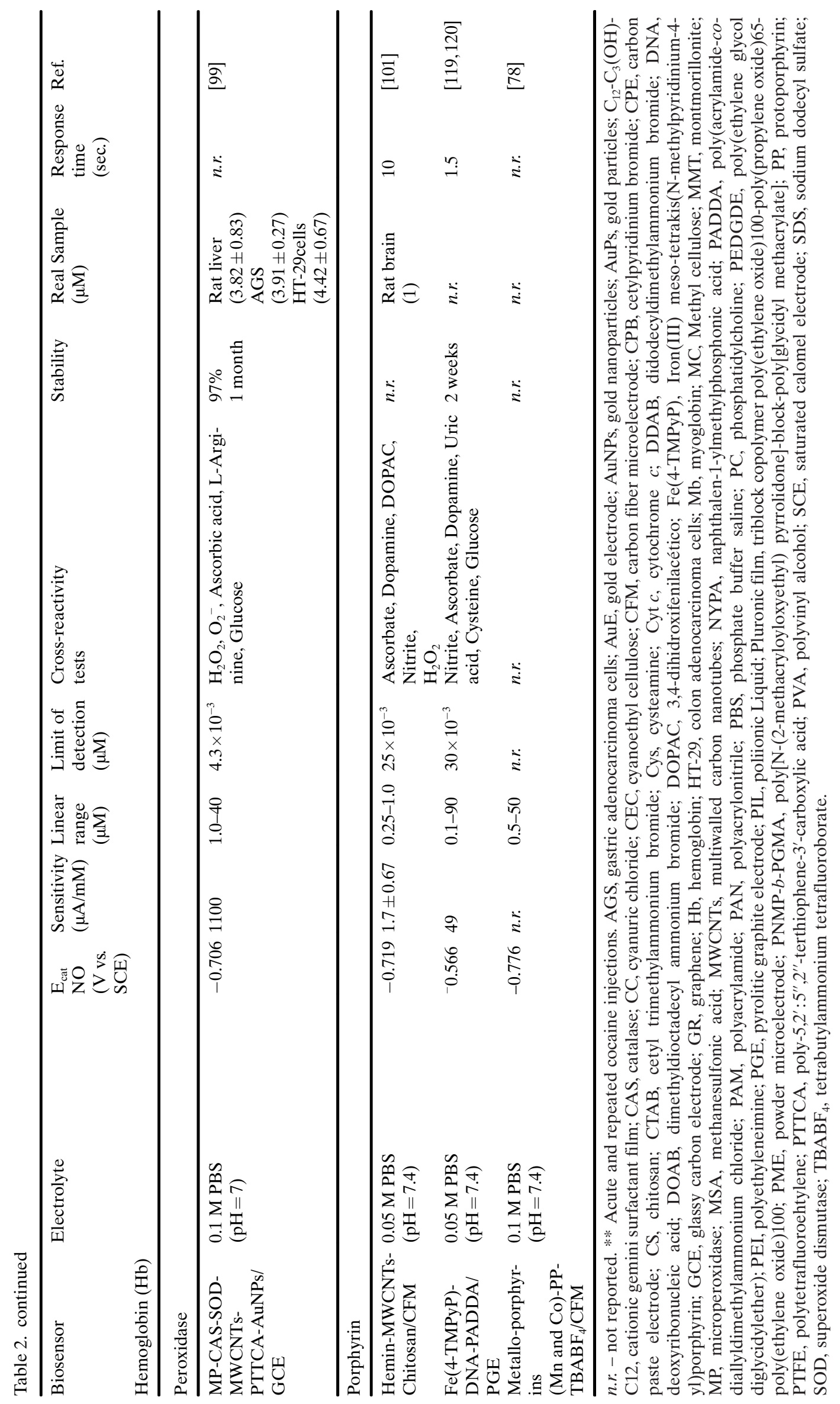


GR, PTTCA-nafion ${ }^{\circledR}$, DNA, SDS-PAM on PGE, Pt microelectrode or GCE showed similar $E_{\text {cat }}$ values of $-0.686,-0.656,-0.606$, and $-0.606 \mathrm{~V}$ vs. SCE for cyt $c$ PIL-GR/PGE [75], cyt $c$-PTTCA-nafion ${ }^{\otimes} / \mathrm{Pt}$ microelectrode [100], cyt $c$-DNA/GCE [80] and cyt $c$-SDS-PAM/ GCE [76], respectively, maybe due to the similar developed microenvironment. No NO potential was indicated for different working electrodes, such as $\mathrm{AuE}$ and $\mathrm{SnO}_{2}$ or $\mathrm{TiO}_{2}[73,77,79]$. Still, a mechanism that consisted on NO binding on the ferrous derivative of $\mathrm{Hb}[\mathrm{Hb} \mathrm{Fe}(\mathrm{II})$ or deoxy $\mathrm{Hb}$ ], forming a stable nitrosyl $\mathrm{Hb}$ species was proposed [73]. Deoxy $\mathrm{Hb}$ reacted with $\mathrm{NO}$ with a stoichiometry of one molecule of $\mathrm{NO}$ per heme $(\mathrm{Hb}$ $\mathrm{Fe}(\mathrm{II})+\mathrm{NO} \rightarrow \mathrm{Hb} \mathrm{Fe}(\mathrm{II})-\mathrm{NO}$ ) as it was observed for $\mathrm{Hb}$ and Mb-based biosensors. The reaction requires anaerobic conditions because $\mathrm{NO}$ is quickly oxidized by $\mathrm{O}_{2}$. $\mathrm{Hb}$ is normally in its oxidized state (Hb Fe(III)), thus NO binding demands the previous reduction of $\mathrm{Hb}$ to $\mathrm{Hb}$ $\mathrm{Fe}(\mathrm{II})$ [73].

In biosensors constructed with MP, a comparable NO reduction peak to those perceived using $\mathrm{Hb}, \mathrm{Mb}$, cyt $c$ and porphyrin modified electrodes was observed at $-0.706 \mathrm{~V}$ vs. SCE [99]. However, the mechanism of the reaction is not clear.

\subsection{Kinetic Parameters}

Information on the kinetics of the reaction at the electrode surface is of great importance to understand the electron transfer processes and assess the success of protein or enzyme immobilization on the different surface electrodes. Therefore, the effect of scan rates on the redox peak currents of the characterized heme proteins and porphyrins has been examined in detail [73,76,93,97,122]; linear relationships have been reported suggesting that the involved reactions corresponded to surface-controlled processes.

Based on equation (8), it is possible to calculate the surface concentration of the electroactive species $\left(\tau^{*}\right)$ [60]:

$\mathrm{Q}=\mathrm{nFA} \tau^{*}$

Where $\mathrm{Q}$ is the charge involved in the reaction; $\mathrm{A}$ is the geometric area of the working electrode; $n$ is the number of the electron transferred; $F$ is the Faraday constant. The majority of studies presented $\tau^{*}$ of $\mathrm{Hb}, \mathrm{Mb}$, cyt $c$, peroxidase and porphyrins in the range of $10^{-10}$ $10^{-12} \mathrm{~mol} / \mathrm{cm}^{2}$ (Table 1). However, there are some exceptions $[80,86]$. The $\tau^{*}$ values reported by Guo et al. [86] of $2.83 \times 10^{-8} \mathrm{~mol} / \mathrm{cm}^{2}$ for $\mathrm{Hb}$ and $9.94 \times 10^{-8} \mathrm{~mol} / \mathrm{cm}^{2}$ for $\mathrm{Mb}$ are much higher (100-10000) than those reached in the other studies possibly due to the large reported "real surface area/apparent electrode area" ratio of the DDABPME. Also, Liu et al. [80] reported the biggest value of surface concentration of $2.46 \times 10^{-6} \mathrm{~mol} / \mathrm{cm}^{2} \quad(10000$ 1000000 times higher when compared with most of the data; Table 1) for cyt $c$-DNA/GCE biosensor that can possibly be explained by the formation of multilayers of cyt $c$ together with DNA chain at the electrode surface. Despite these high results, the usual coverage of electroactive species may still be considered low $\left(10^{-10}\right.$ $10^{-12} \mathrm{~mol} / \mathrm{cm}^{2}$ ), if very elevated sensitivity is desired, because all the active sites of the heme-proteins and porphyrins must be close to the electrode surface and with the proper orientation to promote an efficient electron transfer [123].

The $\mathrm{k}_{\mathrm{s}}$, corresponding to the easiness that the electronic transfer occurs between the biorecognition element and the electrode surface, was also reported for NO biosensors (Table 1 ). This constant was estimated based on Laviron method according to the equation (9) if $\Delta E_{p}$ is greater than $200 / \mathrm{n} \mathrm{mV}$ and equation (10) if the $\Delta \mathrm{E}_{\mathrm{p}}$ is lower than $200 / \mathrm{nmV}$ (where $\Delta \mathrm{E}_{\mathrm{p}}=\mathrm{E}_{\mathrm{pa}}-\mathrm{E}_{\mathrm{pc}} ; \mathrm{n}$ is the number of the electrons transferred; $\alpha$ is the charge transfer coefficient; $\mathrm{R}$ is the ideal gas constant; $\mathrm{T}$ is temperature; F is Faraday constant; $v$ is the scan rate and $\mathrm{m}$ is a parameter related to peak-to-peak separation) $[124,125]$.

$$
\begin{aligned}
& \log \mathrm{k}_{\mathrm{s}}=\alpha \log (1-\alpha)+(1-\alpha) \log \alpha-\log (\mathrm{RT} / \mathrm{nFv})- \\
& (1-\alpha) \alpha \mathrm{F} \Delta \mathrm{E}_{\mathrm{p}} /(2.3 \mathrm{RT}) \\
& \mathrm{k}_{\mathrm{s}}=\mathrm{mnFv} / \mathrm{RT}
\end{aligned}
$$

The large $\mathrm{k}_{\mathrm{s}}$ range for $\mathrm{Hb}$ protein was verified to be 0.10 [93] to $60.3 \mathrm{~s}^{-1}$ [98] (Table 1). Wen at al. [98] obtained the highest value of the electron transfer rate of $60.3 \mathrm{~s}^{-1}$ in a Hb-CS-GR-CTAB/GCE biosensor. These authors described that the promotion of $\mathrm{Hb}$ electron transfer might be mainly due to the three-dimensional architecture of CTAB-GR film and the synergetic behavior of CS with GR. CS also helped to maintain the desirable conformation and activity of $\mathrm{Hb}$ preventing the protein leakage during the electrochemical assay [98].

The most common values reported for $\mathrm{k}_{\mathrm{s}}$ for cyt $c$ and MP are in the range of $0.530 \pm 0.03$ [73] to $2.93 \mathrm{~s}^{-1}$ [75] and $1.31 \mathrm{~s}^{-1}$ [99], respectively (Table 1), being overall in the same order of magnitude. The highest value of $837 \pm$ $40 \mathrm{~s}^{-1}$ was described for hemin-MWCNTs-CS-carbon fiber microelectrode corresponding to multilayers deposited at the microelectrode surface [101].

The Michaelis-Menten constant $\left(K_{\mathrm{m}}\right)$ is a measure of the affinity of the enzyme or protein for its substrate and it defines the substrate concentration (in this case NO) at which the reaction rate is half its maximal value [126]. $K_{\mathrm{m}}$ can be determined by the Lineweaver-Burk equation (11) [124]:

$1 / \mathrm{I}_{\mathrm{ss}}=K_{\mathrm{m}} / \mathrm{I}_{\max } \times 1 / \mathrm{C}+1 / \mathrm{I}_{\max }$

Where $I_{\mathrm{ss}}$ is the steady-state current after addition of the substrate; $C$ is the concentration of the substrate; $I_{\max }$ is the maximum current measured under saturated substrate conditions. 
$K_{\mathrm{m}}$ was only reported for $25 \%$ of the studies (Table 1 ). $\mathrm{Gu}$ et al. [107] obtained for $\mathrm{Hb}$ the highest $K_{\mathrm{m}}$ value of $190 \mu \mathrm{M}$ demonstrating that the system Hb-AuPs-Cys/AuE presents the lowest affinity to NO substrate (Table 1). On the other hand, the maximum affinity was assigned to $\mathrm{Hb}$ immobilized with gold nanoparticles (AuNPs), cellulose and poly(ethylene glycol diglycidylether) (PEDGE) forming the Hb-AuNPs-Cellulose-PEDGE/GCE biosensor $\left(K_{\mathrm{m}}\right.$ of $\left.0.0026 \mu \mathrm{M}\right)$ [90], followed by Hb-CS-GR-CTAB/ GCE $\left(K_{\mathrm{m}}\right.$ of $\left.0.315 \mu \mathrm{M}\right)$ [98]. It is evident that the use of biopolymers, such as cellulose and chitosan, create adequate and compatible microenvironment benefiting the stabilization and the maintenance of the protein activity.

Greater $K_{\mathrm{m}}$ data were noted for cyt $c$ based biosensors when compared to $\mathrm{Hb}$ but information needs to be analyzed with caution since only two studies proposed $K_{\mathrm{m}}$ values [75,76]. The highest value of $K_{\mathrm{m}}$ of $320 \mu \mathrm{M}$ was achieved by a Cyt $c$-SDS-PAM/GCE biosensor [76], while Chen and Zhao [75] described a tenfold lower value of $25.6 \mu \mathrm{M}$ for Cyt $c$-PIL-GR/PGE, which can be explained by the use of a polymerized ionic liquid (PIL). PIL exhibit the properties of ionic liquids but also the merits of polymers contributing favorably for the immobilization of charged proteins. In addition, recent research studies with IL as alternative solvents for enzymatic catalysis exhibited higher enzymatic stability and activity, which make IL promising substitutes for organic solvents in biocatalysis at both laboratory and industrial scale [127]. No reported values of $K_{\mathrm{m}}$ were ascribed for $\mathrm{Mb}$, enzymes and porphyrins used in NO third generation biosensors.

\subsection{Electroanalytical Performance}

NO biosensing requires characterization of numerous parameters such as the linear range, limit of detection and quantification, sensitivity, selectivity, stability and response time (Table 2). These analytical figures of merit are markedly influenced by the selected biorecognition element, the adopted immobilization strategy, the applied detection technique and the optimized electrochemical operational parameters (scan rate, frequency, step potential, amplitude, $\mathrm{pH}$, buffer, etc.). According to the real NO levels in biological systems, high accuracy and sensitivity coupled with low linear range and detection limit are desirable.

Sensitivity data were reported in most of the studies (Table 2). The highest values were presented as being 6330, 1100 and $1068 \mu \mathrm{A} / \mathrm{mM}$ for Hb-PTFE [94], MP-CASSOD-MWCNTs-PTTCA-AuNPs [99] and Mb-MWCNTs [111] modifications in GCE, respectively, while the lowest values were 0.031 and $1.7 \pm 0.67 \mu \mathrm{A} / \mathrm{mM}$ for $\mathrm{Hb}-\mathrm{C}_{12}-\mathrm{C}_{3}$ (OH)- $\mathrm{C}_{12} / \mathrm{GCE}$ [97] and hemin-MWCNTs-CS/CFM [101], respectively. The utilization of nafion ${ }^{\circledR}$ and of some other polymers (PAM, PAN, PEDGDE, polyethyleneimine (PEI), among others) has shown to promote an increase in the biosensor resistance and consequently in sensitivity
[91,100], which can be counterbalanced by the use of highly conducting nanomaterials (AuNPs, MWCNTs and GR).

Linear ranges varying from $0.00004-5.0 \mu \mathrm{M}$ [84] to 0.1-300 $\mu \mathrm{M}[85]$ were reported for $\mathrm{Hb}$ based-biosensors (Table 2). The highest linear range [85] was obtained with $\mathrm{Hb}$ entrapped in a biological membrane component, phosphatidylcholine (PC), forming a Hb-PC/PGE biosensor. On the other hand, the use of montmorillonite (MMT) showed to help decreasing the NO linear range $(0.00004-5.0 \mu \mathrm{M})$ and consequently its limit of detection $\left(20 \times 10^{-6} \mu \mathrm{M}\right.$ for Hb-MMT/PGE) [84]. Moreover, other authors also described low linear ranges for $\mathrm{Hb}$-based biosensors, namely $0.012-5 \mu \mathrm{M}$ for Hb-AuPs-Cys/AuE [107] and $0.0225-2.64 \mu \mathrm{M}$ for Hb-CS-GR-CTAB/GCE [98]. For a different protein, i.e. cyt $c$, the linear ranges varied from $0.5-4.0 \mu \mathrm{M}$ for cyt-c-4-mercaptopyridine/AuE [77] to $100-600 \mu \mathrm{M}$ for cyt $c$-MSA/AuE [79]. It is interesting to see that these two different linear ranges were obtained using different modification of the same bare electrode $(\mathrm{AuE})$ indicating that the material of the bare electrode may not be the main influencing factor concerning NO catalysis. A similar linear range was presented for MP (with values of $1.0-40 \mu \mathrm{M}$ for MP-CAS-SODMWCNTs-PTTCA-AuNPs/GCE) [99]. For hemin biosensors, large linear ranges $(0.1-90 \mu \mathrm{M}[119,120] ; 0.5-50 \mu \mathrm{M}$ [78]) were described with the exception for the heminMWCNTs-Chitosan/CFM biosensor $(0.25-1.0 \mu \mathrm{M})$ [101] showing the advantages of the utilization of microelectrodes (in this case carbon fiber microelectrode) to reach low NO determination levels.

In terms of limits of detection (LOD), the achieved values were quite different ranging from $20 \times 10^{-6} \mu \mathrm{M}$ to $2.85 \mu \mathrm{M}$ mainly due to the dissimilar reached sensitivity (Table 2). Fan et al. [84] reached the lowest LOD (at the picomolar level) with a specific modification of $\mathrm{Hb}$ MMT onto a PGE. It was demonstrated that this type of matrix provided an appropriate immobilization microenvironment, which significantly facilitated the electron communication between $\mathrm{Hb}$ and the PGE [84]. This biosensor exhibited also an acceptable stability retaining $80 \%$ of its initial response during one month. On the contrary, the largest LODs $(1-2.85 \mu \mathrm{M})$ with no indication of the biosensor stability time [102] or only 2 weeks [73] were achieved with the cyt $c$-PAN-CC/ GCE and cyt $c$ or $\mathrm{Hb} / \mathrm{SnO}_{2}$ or cyt $c$ or $\mathrm{Hb} / \mathrm{TiO}_{2}$ electrodes, but overall, the assessed LODs are in the order of $1 \times 10^{-3} \mu \mathrm{M}$.

The biosensors cross-reactivity needs also to be carefully assessed. The most common tested compounds were nitrite, ascorbate, uric acid, cysteine, epinephrine, dopamine, ascorbic acid and glucose (Table 2); overall they did not significantly interfere with $\mathrm{NO}$ detection. Furthermore, $\mathrm{H}_{2} \mathrm{O}_{2}$ and $\mathrm{O}_{2}$ are two interfering species that can react with $\mathrm{NO}$ and form other electroactive species, therefore they were also tested in about $27 \%$ of the studies. Gu et al. [107] suggested that $\mathrm{H}_{2} \mathrm{O}_{2}$ and $\mathrm{O}_{2}$ interferences can be 
reduced by covering a nafion ${ }^{\circledR}$ film onto the modified electrode surface.

A few studies are described in the literature concerning the application of the previously referred biosensors to NO quantification in real samples, namely in oilseed rape (but no value of concentration was presented; [98]), raw blood [107], rat liver $[89,97,99]$ and rat brain $[100,101]$. According to the literature [89,97], the NO levels in rat liver are in the range of $0.6-2.5 \mu \mathrm{M}$; still a higher concentration of $3.82 \pm 0.83 \mu \mathrm{M}$ using microperoxidase as biological recognition element was reported by Abdelwahab et al. [99]. These last authors also analyzed the NO concentration in gastric adenocarcinoma (AGS) and colon adenocarcinoma (HT-29) cells with high NO values of $3.91 \pm 0.27$ and $4.42 \pm 0.67 \mu \mathrm{M}$, respectively [99]. Other successful applications were carried out at NO levels of $0.204 \pm 0.009 \mu \mathrm{M}$ in raw blood using the $\mathrm{Hb}$ AuPs-Cys/AuE biosensor [107]. In rat brain in vivo, NO was also detected at levels varying from $1 \mu \mathrm{M}$ for heminMWCNTs-CS/CFM biosensor [101] to $1.13 \pm 0.03 \mu \mathrm{M}$ for cyt-c-PTTCA-nafion ${ }^{\circledast} / \mathrm{Pt}$ microelectrode [100]. This last NO modified microelectrode, with cyt $c$ immobilized onto a functionalized-conducting polymer (PTTCA) layer, was successfully tested to monitor in vivo $\mathrm{NO}$ fluctuation provoked by the abuse drug cocaine in intact brain [100]; repeated injections of cocaine originated up to $2.13 \pm$ $0.05 \mu \mathrm{M}$ of NO [100]. Also, the hemin-MWCNTs-CS/ CFM biosensor developed by Santos et al. [101] proved to respond adequately to the detection of exogenously applied NO in the rat hippocampus; a small potential window $(-0.5$ to $-1.0 \mathrm{~V}$ vs $\mathrm{Ag} / \mathrm{AgCl})$ was used since high temporal resolution is necessary to monitor in vivo $\mathrm{NO}$ variations. In all reported studies, the response time of NO biosensors was quite fast with a maximum reported of $<20$ seconds [89].

\section{Final Remarks and Future Perspectives}

Third-generation biosensors show great potential for detection and quantification of NO in complex biological milieu, which is extremely important considering its key role in several physiological processes. They exhibit a plethora of advantages being the main ones, the simplicity (no redox mediator is used), sensitivity and selectivity (direct interaction between the redox protein or enzyme with its substrate), easy miniaturization and possibility of in loco measurements. Literature analysis revealed that hemoglobin is the most studied protein for NO detection and glassy carbon and pyrolytic graphite electrodes the most interesting working electrodes to perform biorecognition element immobilization. The use of carbon nanomaterials (carbon nanotubes and graphene) and gold nanoparticles promoted usually an increase in the effective surface area offering electron-conducting tunnels that enhanced the electron transfer rate of the redox protein and porphyrin with the electrode surface and also yielding lower $K_{\mathrm{m}}$ values. The employment of polymers, in many reported works, provided a milieu similar to that of redox proteins and enzymes in native systems. Additionally, the combination of polymer-surfactant allowed forming stable films with ordered multibilayer structure increasing the direct electron transfer and stabilization of these biomolecules. Regardless of these great achievements, there are some limitations to solve. More fundamental research is clearly needed for full understanding the NO catalysis' mechanisms. Long-term stability, particularly in complex matrices and harsh conditions, and the need for lower detection limits are still major problems. Further advances in nanomaterials and proteins' immobilization strategies will allow to overcome these issues and to extend the in vivo applicability of these biosensors. In addition, special addition should be given to try to enlarge the scope of this type of biosensors. Only a limited number of biomolecules have been test to electrocatalyse NO via DET in biosensors. Nitric oxide reductase (NOR) enzyme, that can be isolated from different denitrifying organisms (Pseudomonas aeruginosa, Marinobacter hydrocarbonoclasticus, Pseudonomas stutzeri or Paraccocus denitrificans) and catalyzes the $\mathrm{NO}$ reduction to $\mathrm{N}_{2} \mathrm{O}$ in a two electron/proton reaction [128] was not yet explored in the design of third-generation biosensors; it is a membrane enzyme with high potential for in vivo applications. Also, biotechnology, genetic and protein engineering may contribute with the development of new NO bioelectrocatalysts. Additionally, different biomolecules with DET capacity may be combined in order to obtain synergies and design novel biosensing platforms with enhanced kinetics and electroanalytical characteristics. It is predicted that third-generation biosensors for NO detection will have an increasingly important role in diagnostics of pathologic situations such as cancer, neurodegenerative diseases, amyotrophic lateral sclerosis, diabetes, among others.

\section{Acknowledgements}

FG and LBM thank FCT/MCTES for the fellowship grants SFRH/BD/52502/2014 and SFRH/BPD/111404/ 2015, respectively, which are financed by national funds and co-financed by FSE. CMC acknowledges FCTMCTES funding through project PTDC/BBB-BQB/ 0129/2014 (FCT/MCTES). This work was supported by the PTDC/BB-BQB/0129/2014 project (FCT/MCTES) and also by the Associate Laboratory Research Unit for Green Chemistry - Technologies and Processes Clean LAQV, financed by national funds from FCT/MEC (UID/QUI/50006/2013) and co-financed by the ERDF under the PT2020 Partnership Agreement (POCI-010145-FEDER-007265). Funding through REQUIMTE project entitled "NOR-based biosensor for nitric oxide detection in biological and environmental samples" is also acknowledged. 


\section{References}

[1] L. B. Maia, J. J. G. Moura, Chem. Rev. 2014, 114, 52735357.

[2] B. Kartal, W. J. Maalcke, N. M. De Almeida, I. Cirpus, J. Gloerich, W. Geerts, Nature 2011, 479, 127-130.

[3] A. L. Ducluzeau, R. Van Lis, S. Duval, B. SchoeppCothenet, M. J. Russell, W. Nitschke, Trends Biochem. Sci. 2009, 34, 9-15.

[4] I. Moura, J. J. Moura, S. R. Pauleta, L. B. Maia, Metalloenzymes in denitrification: Applications and environmental impacts, Royal Society of Chemistry, 2016.

[5] M. S. Jetten, M. Strous, K. T. van de Pas-Schoonen, J. Schalk, U. G. van Dongen, A. A. van de Graaf, FEMS Microbiol. Rev. 1998, 22, 421-437.

[6] K. F. Ettwig, M. K. Butler, D. Le Paslier, E. Pelletier, S. Mangenot, M. M. M. Kuypers, Nature 2010, 464, 543-548.

[7] R. F. Furchgott, M. H. Carvalho, M. T. Khan, K. Matsunaga, Blood Vessels 1987, 24, 145-149.

[8] L. J. Ignarro, G. M. Buga, K. S. Wood, R. E. Byrns, G. Chaudhuri, Proc Natl Acad Sci USA 1987, 84, 9265-9269.

[9] R. M. Palmer, A. G. Ferrige, S. Moncada, Nature 1987, 327, 524-526.

[10] R. M. Rapoport, F. Murad, Circ. Res. 1983, 52, 352-357.

[11] S. Moncada, R. M. Palmer, E. A. Higgs, Pharmacol. Rev. 1991, 43, 109-142.

[12] R. A. Johnson, R. H. Freeman, Am. J. Hypertens. 1992, 5, 919-922.

[13] V. Lahera, J. Salazar, M. G. Salom, J. C. Romero, J Hypertens. 1992, 10, 179.

[14] G. Brock, L. Nunes, H. Padma-Nathan, S. Boyd, T. F. Lue, Urology 1993, 42, 412-417.

[15] E. McGuffey, Am. Pharm., 1993, 20.

[16] J. Koglin, T. Glysing-Jensen, J. S. Mudgett, M. E. Russell, Circulation 1998, 97, 2059-2065.

[17] M. Weis, T. N. Kledal, K. Y. Lin, S. N. Panchal, S. Z. Gao, H. A. Valantine, Circulation 2004, 109, 500-505.

[18] L. Fang, B. J. Nowicki, Y. L. Dong, C. Yallampalli, Am. J. Obstet. Gynecol. 1999, 181, 601-609.

[19] N. Hopkins, Y. Gunning, D. F. O'Croinin, J. G. Laffey, P. McLoughlin, J. Pathol. 2006, 209, 198-205.

[20] J. W. Choi, Clin. Chim. Acta 2003, 336, 83-87.

[21] J. J. Levine, M. J. Pettei, E. Valderrama, D. M. Gold, B. H. Kessler, H. Trachtman, J. Pediatr. Gastroenterol. Nutr. 1998, 26, 34-38.

[22] C. Martinez, Y. Juarranz, C. Abad, A. Arranz, B. G. Miguel, F. Rosignoli, J. Leukocyte Biol. 2005, 77, 729-738.

[23] G. M. Pieper, Hypertension 1998, 31, 1047-1060.

[24] G. N. Andersen, K. Caidahl, E. Kazzam, A. S. Petersson, A. Waldenstrom, L. Mincheva-Nilsson, Arthritis Rheum. 2000, 43, 1085-1093.

[25] E. Fabrega, F. Casafont, J. De La Pena, J. Berrazueta, G. De Las Heras, J. Amado, Nitric oxide production in hepatic cell rejection of liver transplant patients, Transplantation proceedings, Elsevier 1997, pp. 505-516.

[26] W. K. Alderton, C. E. Cooper, R. G. Knowles, Biochem. J. 2001, 357, 593-615.

[27] S. Pfeiffer, B. Mayer, B. Hemmens, Angew. Chem. Int. Ed. 1999, 38, 1714-1731.

[28] D. J. Stuehr, Biochim. Biophys. Acta 1999, 1411, 217-230.

[29] J. O. Lundberg, M. T. Gladwin, A. Ahluwalia, N. Benjamin, N. S. Bryan, A. Butler, Nat. Chem. Biol. 2009, 5, 865-869.

[30] J. O. Lundberg, E. Weitzberg, M. T. Gladwin, Nat. Rev. Drug Discovery 2008, 7, 156-167.

[31] L. B. Maia, J. J. Moura, J. Biol. Inorg. Chem. 2011, 16, $443-$ 460.
[32] L. B. Maia, J. J. Moura, J. Biol. Inorg. Chem. 2015, 20, 403433.

[33] L. B. Maia, V. Pereira, L. Mira, J. J. Moura, Biochemistry 2015, 54, 685-710.

[34] J. R. Lancaster, Jr., Nitric Oxide 1997, 1, 18-30.

[35] M. Sato, N. Hida, Y. Umezawa, Proc. Natl. Acad. Sci. USA 2005, 102, 14515-14520.

[36] J. L. Wallace, R. C. Woodman, Methods 1995, 7, 55-58.

[37] S. Hilderbrand, M. Lim, S. Lippard, In topics in fluorescence spectroscopy, (Eds. C. D. Geddes and J. R. Lakowicz), Springer 2005.

[38] H. Kojima, M. Hirotani, Y. Urano, K. Kikuchi, T. Higuchi, T. Nagano, Tetrahedron Lett. 2000, 41, 69-72.

[39] H. Kojima, N. Nakatsubo, K. Kikuchi, S. Kawahara, Y. Kirino, H. Nagoshi, Anal. Chem. 1998, 70, 2446-2453.

[40] A. M. Miles, Y. Chen, M. W. Owens, M. B. Grisham, Methods 1995, 7, 40-47.

[41] T. Nagano, T. Yoshimura, Chem. Rev. 2002, 102, 1235-1270.

[42] E. Sasaki, H. Kojima, H. Nishimatsu, Y. Urano, K. Kikuchi, Y. Hirata, et al., J. Am. Chem. Soc. 2005, 127, 3684-3695.

[43] L. C. Green, D. A. Wagner, J. Glogowski, P. L. Skipper, J. S. Wishnok, S. R. Tannenbaum, Anal. Biochem. 1982, 126, 131-138.

[44] W. L. Daniel, M. S. Han, J.-S. Lee, C. A. Mirkin, J. Am. Chem. Soc. 2009, 131, 6362-6363.

[45] D. Li, Y. Ma, H. Duan, W. Deng, D. Li, Biosens. Bioelectron. 2018, 99, 389-398.

[46] B. M. Jayawardane, S. Wei, I. D. McKelvie, S. D. Kolev, Anal. Chem. 2014, 86, 7274-7279.

[47] D. M. Zurcher, Y. J. Adhia, J. D. Romero, A. J. McNeil, Chem. Commun. 2014, 50, 7813-7816.

[48] N. Lopez-Ruiz, V. F. Curto, M. M. Erenas, F. Benito-Lopez, D. Diamond, A. J. Palma, Anal. Chem. 2014, 86, 9554-9562.

[49] L. B. Maia, J. J. Moura, Methods Mol. Biol. 2016, 1424, 81102.

[50] J. Vasquez-Vivar, P. Martasek, N. Hogg, H. Karoui, B. S. Masters, K. A. Pritchard, Jr., Methods Enzymol. 1999, 301, 169-177.

[51] T. Yoshimura, H. Yokoyama, S. Fujii, F. Takayama, K. Oikawa, H. Kamada, Nat. Biotechnol. 1996, 14, 992-994.

[52] E. M. Hetrick, M. H. Schoenfisch, Annu. Rev. Anal. Chem. 2009, 2, 409-433.

[53] J. L. Howland, Methods in nitric oxide research. (Eds. M. Feelisch and J. S. Stamler), pp 712. John Wiley and Sons, New York, 1996, ISBN 0-471-95524-8, Biochem. Educ. 1997, 25, 184-195.

[54] A. M. Leone, V. W. Furst, N. A. Foxwell, S. Cellek, S. Moncada, Biochem. Biophys. Res. Commun. 1996, 221, 3741.

[55] B. W. Allen, J. Liu, C. A. Piantadosi, Electrochemical detection of nitric oxide in biological fluids, Methods in enzymology, Academic Press, 2005, pp. 68-77.

[56] A. Hulanicki, S. Glab, F. Ingman, Chemical sensors: definitions and classification, Pure and Applied Chemistry, 1991, p. 1247.

[57] D. R. Thévenot, K. Toth, R. A. Durst, G. S. Wilson, Biosens. Bioelectron. 2001, 16, 121-131.

[58] J. Castillo, S. Gáspár, S. Leth, M. Niculescu, A. Mortari, I. Bontidean, Sens. Actuators B 2004, 102, 179-194.

[59] A. Koyun, E. Ahlatcioglu Özerol, Y. İpek, Biosensors and Their Principles, 2012.

[60] D. Grieshaber, R. MacKenzie, J. Vörös, E. Reimhult, Sensors 2008, 8, 1400-1458.

[61] J. L. Hammond, N. Formisano, P. Estrela, S. Carrara, J. Tkac, Essays Biochem. 2016, 60, 69-80. 
[62] D. W. Kimmel, G. LeBlanc, M. E. Meschievitz, D. E. Cliffel, Anal. Chem. 2012, 84, 685-707.

[63] B. Kowalewska, K. Jakubow, Sens. Actuators B 2017, 238, 852-861.

[64] N. J. Ronkainen, H. B. Halsall, W. R. Heineman, Chem. Soc. Rev. 2010, 39, 1747-1763.

[65] W. Putzbach, N. J. Ronkainen, Sensors 2013, 13, 4811-4840.

[66] P. Rafighi, M. Tavahodi, B. Haghighi, Sens. Actuators B 2016, 232, 454-461.

[67] C. Li, B. Guo, X. M. Guo, F. Wang, $R S C A d v$. 2016, 6, 90480-90488.

[68] Y. M. Liu, C. Punckt, M. A. Pope, A. Gelperin, I. A. Aksay, ACS Appl. Mater. Interfaces 2013, 5, 12624-12630.

[69] B. J. Privett, J. H. Shin, M. H. Schoenfisch, Chem. Soc. Rev. 2010, 39, 1925-1935.

[70] R. S. Freire, C. A. Pessoa, L. D. Mello, L. T. Kubota, J. Braz. Chem. Soc. 2003, 14, 230-243.

[71] S. R. Chinnadayyala, A. Kakoti, M. Santhosh, P. Goswami, Biosens. Bioelectron. 2014, 55, 120-126.

[72] A. Sassolas, L. J. Blum, B. D. Leca-Bouvier, Biotechnol. Adv. 2012, 30, 489-511.

[73] E. Topoglidis, Y. Astuti, F. Duriaux, M. Grätzel, J. R. Durrant, Langmuir 2003, 19, 6894-6900.

[74] Y. Xu, C. Hu, S. Hu, Sens. Actuators B 2010, 148, 253-258.

[75] H. Chen, G. Zhao, J. Solid State Electrochem. 2012, 16, 3289-3297.

[76] X. Chen, H.-Y. Long, W.-L. Wu, Z.-S. Yang, Thin Solid Films 2009, 517, 2787-2791.

[77] T. Haruyama, S. Shiino, Y. Yanagida, E. Kobatake, M. Aizawa, Biosens. Bioelectron. 1998, 13, 763-769.

[78] C. Z. Li, S. Alwarappan, W. Zhang, N. Scafa, X. Zhang, Am. J. Med. Sci. 2009, 1, 274-282.

[79] F. Lisdat, B. Ge, W. Stöcklein, F. W. Scheller, T. Meyer, Electroanalysis 2000, 12, 946-951.

[80] Y.-C. Liu, J. Zhao, W.-L. Wu, Z.-S. Yang, Electrochim. Acta 2007, 52, 4848-4852.

[81] M. Q. Xu, J. F. Wu, G. C. Zhao, Sensors 2013, 13, 74927504.

[82] C. Fan, X. Chen, G. Li, J. Zhu, D. Zhu, H. Scheer, Phys. Chem. Chem. Phys. 2000, 2, 4409-4413.

[83] C. Fan, G. Li, J. Zhu, D. Zhu, Anal. Chim. Acta 2000, 423, 95-100.

[84] C. Fan, X. Liu, J. Pang, G. Li, H. Scheer, Anal. Chim. Acta 2004, 523 (2004) 225-228.

[85] C. Fan, J. Pang, P. Shen, G. Li, D. Zhu, Anal. Sci. 2002, 18, $129-132$.

[86] Z. Guo, J. Chen, H. Liu, C. Cha, Anal. Chim. Acta 2008, 607, 30-36.

[87] X. He, L. Zhu, Electrochem. Commun. 2006, 8, 615-620.

[88] S. Jia, J. Fei, J. Deng, Y. Cai, J. Li, Sens. Actuators B 2009, $138,244-250$.

[89] S. Jia, J. Fei, J. Zhou, X. Chen, J. Meng, Biosens. Bioelectron. 2009, 24, 3049-3054.

[90] F. Li, M. Nie, X. He, J. Fei, Y. Ding, B. Feng, Microchim. Acta 2014, 181, 1541-1549.

[91] P. Li, Y. Ding, Z. Lu, Y. Li, X. Zhu, Y. Zhou, Talanta 2013 , $115,228-234$

[92] X. Liu, L. Shang, J. Pang, G. Li, Biotechnol. Appl. Biochem. 2003, 38, 119-122.

[93] X. Liu, L. Shang, Z. Sun, G. Li, J. Biochem. Biophys. Methods 2005, 62, 143-151.

[94] Q. Lu, S. Hu, Chem. Phys. Lett. 2006, 424, 167-171.

[95] J. Pang, C. Fan, X. Liu, T. Chen, G. Li, Biosens. Bioelectron. 2013, 19, 441-445.

[96] W. Shan, P. He, N. Hu, Electrochim. Acta 2005, 51, 432-440.
[97] F. Wang, X. Chen, Y. Xu, S. Hu, Z. Gao, Biosens. Bioelectron. 2007, 23, 176-182.

[98] W. Wen, W. Chen, Q.-Q. Ren, X.-Y. Hu, H.-Y. Xiong, X.-H. Zhang, Sens. Actuators B 2012, 166-167, 444-450.

[99] A. A. Abdelwahab, W. C.A. Koh, H.-B. Noh, Y.-B. Shim, Biosens. Bioelectron. 2010, 26, 1080-1086.

[100] W. C.A. Koh, M. A. Rahman, E. S. Choe, D. K. Lee, Y.-B. Shim, Biosens. Bioelectron. 2008, 23, 1374-1381.

[101] R. M. Santos, M. S. Rodrigues, J. Laranjinha, R. M. Barbosa, Biosens. Bioelectron. 2013, 44, 152-159.

[102] S. H. Takahashi, S. I. C. de Torresi, Synth. Met. 2009, 159, 2159-2161.

[103] J. G. Pacheco, M. F. Barroso, H. P.A. Nouws, S. Morais, C. Delerue-Matos, 21 - Biosensors A2 - Larroche, Christian (Eds. M. Á. Sanromán, G. Du and A. Pandey), Current Developments in Biotechnology and Bioengineering, Elsevier, 2017, pp. 627-648.

[104] T. Jesionowski, J. Zdarta, B. Krajewska, Adsorption 2014, $20,801-821$.

[105] C. Helms, D. B. Kim-Shapiro, Free Radical Biol. Med. 2013, $61,464-472$.

[106] A. R. Pereira, G. C. Sedenho, J. C.P. Souza, F. N. Crespilho, An. Acad. Bras. Cienc. 2018, 90, 825-857.

[107] H.-Y. Gu, A.-M. Yu, S.-S. Yuan, H.-Y. Chen, Anal. Lett. 2002, 35, 647-661.

[108] D. Pletcher, Studies of metal deposition and dissolution using microelectrodes (Eds. M. I. Montenegro, M. A. Queirós and J. L. Daschbach), Microelectrodes: Theory and applications, Springer Netherlands, Dordrecht, 1991, pp. 463-475.

[109] G. A. Ordway, D. J. Garry, J. Exp. Biol. 2004, 207, 3441-6.

[110] S. Kröning, F. W. Scheller, U. Wollenberger, F. Lisdat, Electroanalysis 2004, 16, 253-259.

[111] L. Zhang, G.-C. Zhao, X.-W. Wei, Z.-S. Yang, Electroanalysis 2005, 17, 630-634.

[112] J. Wang, M. Li, Z. Shi, N. Li, Z. Gu, Anal. Chem. 2002, 74, 1993-1997.

[113] J. Petrović, R. A. Clark, H. Yue, D. H. Waldeck, E. F. Bowden, Langmuir 2005, 21, 6308-6316.

[114] H. B. Dunford, T. Araiso, D. Job, J. Ricard, R. Rutter, L. P. Hager, Peroxidases, (Eds. H. B. Dunford, D. Dolphin, K. N. Raymond and L. Sieker), The biological chemistry of iron: A look at the metabolism of iron and its subsequent uses in living organisms proceedings of the NATO advanced study - Institute held at Edmonton, Alberta, Canada, August 13-September 4, 1981, Springer Netherlands, Dordrecht, 1982, pp. 337-55.

[115] E. Casero, M. Darder, F. Pariente, E. Lorenzo, Anal. Chim. Acta 2000, 403, 1-9.

[116] J. H. Zagal, F. Bedioui, J.-P. Dodelet, N4-macrocyclic metal complexes, Springer Science \& Business Media, 2007.

[117] M. T. de Groot, M. Merkx, A. H. Wonders, M. T. M. Koper, J. Am. Chem. Soc. 2005, 127, 7579-7586.

[118] N. J. Tao, G. Cardenas, F. Cunha, Z. Shi, Langmuir 1995, 11, 4445-4448.

[119] J. Lei, H. Ju, O. Ikeda, Electrochim. Acta 2004, 49, 24532460.

[120] J. Lei, H. Ju, O. Ikeda, Sensors 2005, 5, 171-184.

[121] H. Ole, J. Ulstrup (eds.), Bioinorg. Chem. Springer Science \& Business Media, 2007.

[122] Y.-M. Li, H.-H. Liu, D.-W. Pang, J. Electroanal. Chem. 2004, 574, 23-31.

[123] J. Yu, J. Ma, F. Zhao, B. Zeng, Electrochim. Acta 2007, 53, 1995-2001.

[124] E. Laviron, J Electroanal Chem Interfacial Electrochem 1974, 52, 355-393. 
[125] J. F. Rusling, B. Wang, S.-e. Yun, Electrochemistry of redox enzymes, Bioelectrochemistry, John Wiley \& Sons, Ltd, 2008, pp. $39-85$.

[126] R. Roskoski, Michaelis-Menten kinetics, The comprehensive pharmacology reference, Elsevier, New York, 2007, pp. 110.

[127] A. P. Tavares, O. Rodriguez, E. A. Macedo, Biotechnol. Bioeng. 2008, 101, 201-207.

[128] P. Tavares, A. S. Pereira, J. J. G. Moura, I. Moura, J. Inorg. Biochem. 2006, 100, 2087-2100. 